\title{
Promotion Of Primary Health Care In Pakistan: A Case Study Of The Role Of Non-Governmental Organizations In Promoting Primary Health Care In Karachi
}

\author{
Fateh Muhmmad Burfat \\ Yaqub \\ \& \\ Naima Saeed \\ Department of Sociology \\ University of Karachi \\ Misbah B. Qureshi \\ Institute of Gender Studies \\ University of Sindh, Jamshoro
}

\begin{abstract}
The present study "Promotion of Primary Health Care in Pakistan: A Case Study of the Role of Non-Governmental Organizations (NGOs) in Promoting Primary Health Care in Karachi" is aimed at determining the role of NGOs in the promotion of primary health Care sector in Pakistan with special reference to Karachi. The primary objective of this research is to evaluate the role and performance of relevant NGOs working in Karachi in the health sector. It is a quantitative research. A questionnaire based to obtain the opinions of respondents. The health care is the basic responsibility of the state. However, the NGOs play their role in promoting the health care facilities. It was noted that the primary health care system is still not working properly. NGO sector was given a wide room and finances but unfortunately they did not make the required contribution. Their lack of technical knowledge and accountability was a factor in their failure. The prevailing attitude towards health care among the masses has not changed despite the efforts of the NGO sector. Therefore the basic health conditions of the masses at the grass roots level continue to be poor. The stake holders in the health care sector should rethink about their strategies to improve health care facilities in Karachi.
\end{abstract}

\section{تلخيص مقالْ}

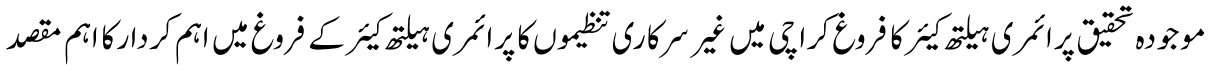

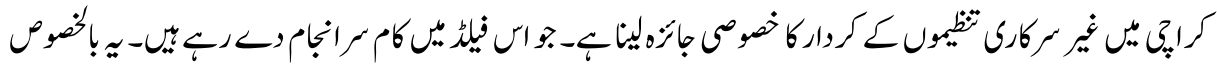

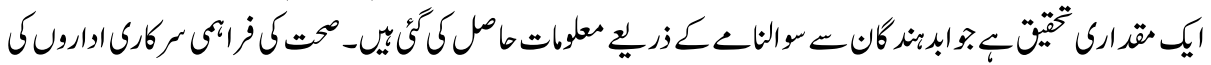

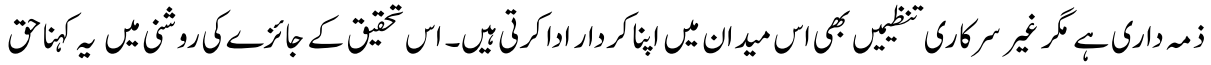

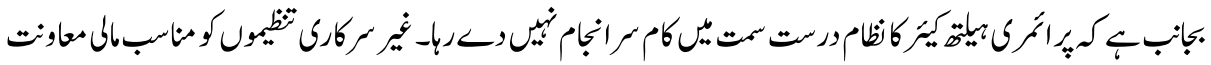

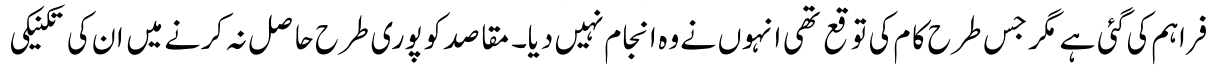

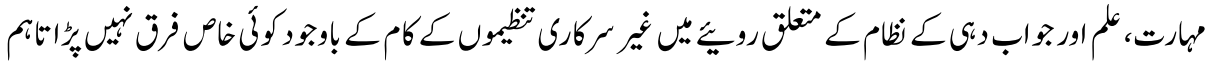

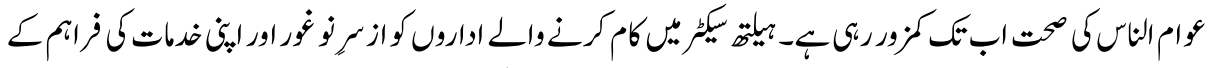

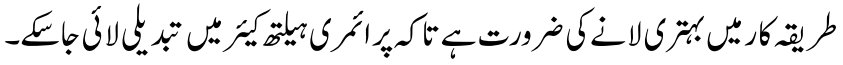




\section{Introduction}

The access to health care is a basic human right (Ali, 2000). This right is duly accepted in the Article 25 (1) of the Universal Declaration of Human Rights (UNO, 1948; UDHR, 1948; Youth for Human Rights International, 2010). The concept of PHC has been defined as: "Primary health care is essential health based on practical, scientifically sound and socially acceptable methods and technology, made universally, accessible to individuals and families in the community through their full participation and at a cost the community and country can afford to maintain at every stage of their development in the spirit of self-reliance and self determination" (WHO, 1978). The PHC approach needs effort by the community, NGOs, and Government at grass-roots level. The role of NGOs in the promotion of health was considered crucial (Karim, 1998; NGORC, 1996; SPO, 1994; TVO, 1994; UNDP, 1997).

\section{Basic Features of Health}

\section{Definition of Health}

Health has been seen and defined from different standpoints. The biomedical approach described health as a deviation from the biological norm, and termed health as an absence of disease. This approach ignores the presence of psychological entities, and lays stress on medical and technical treatment (Henslin, 2005). The holistic approach laid emphasis on environmental, socio-economic, psychological, and physiological factors in its definition of health (Leighninger and Popple, 2000; Benton, 2000).

J.M. Henslin in his discussion on "Medicine and Health" (2005: 542-575) described health as a "human condition measured by four components: physical, mental, social and spiritual." Henslin explained theoretical approaches to the issues of health. He considered AIDS as a threat to health, and mentioned some issues in health care. W. Benton (2000:74) saw health as a state of complete physical, social, mental, and economic well-being and not merely the absence of disease and infirmity. He noted: "Health is a right difpofication of all the body and of all its parts; confiding in a due temperature, a right confirmation. Just connection and ready and free exercise of the several vital functions" (AKU, 1987). The definitions just mentioned suggest that the issues of health care need to be seen in their entirety. Health and illness are seen differently in societies. The industrialized countries have more developed public health systems. The availability of the clean water is taken for granted in the industrialized countries. In contrast, more than 1 billion of the world's people are without approach to clean water supply (Kamal, 2010; WB, 93; WHO, 2003).

\section{The Components of Health}

Three elements of health were identified by experts back in 1941. These are: physical, mental, and social. In this identification the spiritual aspect was not included. It may be 
noted that religion is closely connected with spiritual matters. (Henslin, 2005:488-517; Thio, 1996:385-407). The functionalists' perspective emphasizes that religion provides practical directions on how to live our everyday lives. (Henslin, 2005: 489-492; Thio, 1996:389-391). The adherents to the teachings of Judaism's, Christianity, and Islam are less likely to abuse alcohol and illegal drugs than other people. (Henslin, 2005). The four components of health: physical, mental, social, and spiritual need to be promoted through individual and collective efforts of the community. The study of disease and disability patterns in the population calls for serious research. (Henslin, 2005; Twaddle; 38-48). Health policy is dependent on the correct assessment of issues related to the four components of health (Henslin, 2005:524; WHO, 2004).

\section{The Sociological Factors of Heath}

Health is not confined only to consideration of biological matters. Health is intimately related to society (Henslin, 2005; Robbins, 2007; Twaddle, 1987; Thio, 1996). Four sociological factors have visible implications for health. These are: structure of society, lifestyle of citizen, public health system, and the environment.

\section{Structure of Society}

The level of inequality and gap between rich and poor in the society impacts on the standard of health. (Arif, 2002; Borges, 1995; Iqtidar, 2003; Henslin, 2005:523; UNDP, 2003; WB, 1993; Zaidi, 1995).The access to medical facilities influences the standard of health. Health inequality manifests itself in many ways. For instance, higher infant mortality rates and lower life expectancy is found in poor people (Bhutta, 2011; Bryant, 2003; PMA, 2011). The pattern of disease differs in the well-to-do and the poor. Obesity is generally seen among the more affluent (Gulf, 2006; Sheikh, 2008; WHO, 2004).

\section{Lifestyle of Citizens}

The lifestyles associated with poor health include: poor diet, lack of exercise, excessive use of alcohol and drugs, smoking cigarettes and social isolation (Bhutta, 2011, WHO, 2011). The legal ban on smoking cigarettes needs community support for its implementation (WB, 1993). The changes in lifestyles and its effects on health, is a subject for serious research.

\section{Public Health System}

The state of health is closely related to health politics of nations (WB, 1993). Public health system strives to improve health conditions of the citizens. The system is composed of government-run health programs. The focus of these programs is to ensure 
clean drinking water, sewage and sanitation services, and measures against infectious diseases (Iliyas, 2003; Munir, 2002; Zaidi, 1995). Support for public health programs often sought from donors and NGOs. Health care system, comprised of clinics, Hospitals and other medical facilities.

\section{The Environment}

Major health risks are posed by the environment constructed by humans. The incidents of Chernobyl nuclear reactor in Russia, and leak from a pesticides factory in Bhopal (India) are lasting reminders of environmental risk to health. (Broughton, 2005:4-6; UNSCEAR, 2011). The environmental profile of Pakistan (GOP, 1997) provides directions to deal with the issues related to the environment. Pollution in Karachi and other cities of the country pose serious risk to health (Younis, 2004).

\section{Fundamentals of PHC}

The idea of primary health care was suggested in a book jointly authored by K. Newell and E. Amundsen in 1973. The forward-looking concept of primary health care was formally adopted by the WHO in the Alma Ata Conference in 1978 (Helander, 2000; WHO, 2008).

In the Alma Ata Declaration (WHO, 1978), primary health care has been defined as "essential health care based on practical, scientifically sound and socially acceptable methods and technology made universally, accessible to individuals and families in the community through their full participation and at a cost that the community and the country can afford to maintain at every stage of their development in the spirit of selfreliance and self-determination."

\section{The Concept of PHC}

The definition of PHC points to at least five characteristics of PHC. These are: (1) The PHC should reach the needy. It is an essential health care which is based on technology. It has methods which are practical, scientifically sound, and socially acceptable. (2) The PHC services should be acceptable to the community, and involve the participation of the community. (3) The health services must be effective, and available at affordable costs. (4) The PHC services should be integrated with the system of the country. (5) The PHC program should be multi-sectoral in approach (AKU, 1995; WHO, 2004).

The five characteristics described above, can be actualized provided the essential elements of a PHC program are followed. The eight elements are: (1) Education concerning prevailing health problems and the methods of identifying preventing, and 
controlling them. (2) Promotion of food supply and proper nutrition, an adequate supply of save water and basic sanitation. (3) Maternal and child health care, including family planning. (4) Immunizations against the major infection diseases. (5) Prevention and control of locally endemic diseases. (6) Appropriate treatment of common diseases and injuries. (7) Promotion of mental health. (8) Provision of essential drugs (AKU, 1993; Ali, 2001; GOP, 2008-9; WHO, 1978).

The concept of PHC and its ultimate goal to ensure better health for all has been pursued with vigor by the WHO. Components identified in another WHO document. These elements are: (1) Reducing exclusion and social disparities in health. (2) Organizing health services around people's needs and expectations. (3) Integrating health into all sectors. (4) Pursuing collaborative methods of policy dialogue. (5) Increasing stakeholder participation (WHO, 2003).

\section{The Planning of PHC}

The planning of PHC is guided by three basic principles. These are: equity, effectiveness, and efficiency. In planning, these principles are kept inter-linked in their application (WHO, 1978).

\section{Equity}

It has two aspects. One, every citizen should be entitled to receive health care facilities. Two, the needs of all individuals should be taken in consideration. However, it does not imply that everyone should receive equal care. Equity calls for health care according to need (AKU, 1995; Khan, 2009; PMA, 2012).

\section{Effectiveness}

Monitoring of the PHC program is essential. It ensures the effectiveness of the services being offered. Poor effectiveness is reflected in poor health statistics. The effectiveness of program becomes possible only through better health education and dedication of the health staff.

\section{Efficiency}

The efficiency of the program is realized through efforts at ensuring equity and effectiveness. Efficiency of the program demands that it should be low cost, and yet geared to produce favorable results. However in the developing countries, including Pakistan, these three principles are often ignored while planning PHC programs (Helander, 2000; Zaidi, 2000). 


\section{The Implementation of PHC}

The success of PHC programs is seen in the successful implementation of PHC plans. The government obtains help from the community and NGOs. The factor of PHC quality becomes paramount. The role of hospitals and the doctor-patient relationship are crucial factors in the quality of PHC services.

\section{The Role of hospitals in PHC}

The PHC approach envisages that the hospitals become responsive to the health needs of the community in their locality. In this context the Aga Khan Foundation (AKF), in collaboration with the WHO, organized a conference in 1981. The recommendations highlighted: (1) the role of hospitals in promoting PHC goals with community participation. (2) The role of hospitals in providing intimate support to PHC in activities. (3) The role of hospitals in motivating health related staff to PHC. (4) The role of hospitals in research related to health services (AKF, 1981).

\section{The Doctor Patient-Relationship}

The implementation of PHC depends on sound relationship between the doctor and his patient. The relationship is influenced by the continued availability and desire of the doctor to serve individual cases in times of need. The quality of comprehensive PHC also depends on the cost involved in obtaining the services of the efficient doctors (AKU, 1987; USAID, 2012; WHO, 2005).

\section{PHC in Pakistan}

The Alma Ata Declaration of 1978 on health was adopted by all the signatory countries to meet health care needs of people. Later the WHO adopted a resolution in 1998 to provide directions for the new global Health for ALL policy. The new policy "Health for ALL in the $21^{\text {st }}$ Century" succeeds the "Health for ALL in the Year 2000". In the new policy, the concept of social justice is explained in key values, goals, objectives, and targets (Braveman, 1994; WHO, 1978). In India the planning of PHC has been done covering "Rural PHC" and "Urban PHC". (Gupta and Muhajan, 2005:489-496). The government of Pakistan, however, introduced the PHC services prior to the 1978 Alma Ata Declaration of Health for ALL by the year 2000" (Iliyas and Soomro, 2000:91-96). 


\section{The Framework of PHC in Pakistan}

The framework of PHC is structured on Basic Health Units (BHUs), Rural Health Centers (RHCs), and supporting facilities such as dispensaries, maternity and child health centers, and sub-centers. Medical staff is appointed by the Government to ensure smooth functioning of the system. (GOP, 1994)

\section{The Structure of PHC}

The structure of PHC provides a systematic link between the village community and the whole health system (Iliyas, 2003; Lashari, 2004). Subject to the spread and density of population, a Basic Health Unit serves 5,000-10,000 population. The services in a BHU include: Maternity and Child Health $(\mathrm{MCH})$ services. Child care, malaria control, immunization, diarrheal disease control, mental health, and school health services (GOP, 2007).

Five to ten BHUs are linked to a Rural Health Centre. The RHC has facility for X-ray, and provision for minor surgery. The RHC has about 25 beds capacity. The RUC is linked to Tehsil / Talulka Hospital. The hospital at the District Headquarters has all the facilities related to health care (GOP, 2001).

The PHC programs of malaria control, immunization, diarehea disease control, and maternity and child health services. The provision of clean water facilities, sewage and sanitation needs, and protection against pollution is the pressing problems of urban areas (GOP, 1991; Syed, 2000).

\section{The Functioning of PHC}

The structure of PHC becomes dynamic and functions through the combined efforts of members of the health team in each centre. The team generally comprises: Medical officer, Nurses, Lady Health visitors, Midwives, Vaccinator, Dispenser, and Administrative Staff (Khalid and Iliyas, 1990). The broad functions of the health team in a center are: Provision of medical care, control of communicable diseases, supply of environmental sanitation, maternal and child health services, health education, and implementing the national health care programs (GOP, 2008-9; Shaikh, 2003).

The scope of comprehensive PHC is considered to be very extensive, and beyond the reach of most developing countries. (Waslh, 1980). The UNICEF, therefore, proposed a selective PHC (SPHC) approach. It includes, the mother and child health lays emphasis on six elements termed GOBI-FF. It stands for: (growth Monitoring), O (ORS), B (breast Feeding), I (Immunization), F (Family Planning), and (Family Education). The effectiveness of SPHC approach has been debated in the literature (AKU, 1983; WHO, 1978). 


\section{Current Health Situation in Pakistan}

A number of studies have appeared on the health situation in the country. (Bhutta, 2011; Burki, 2008; Lashari, 2004; WHO, 2010; Zaidi, 1988). K.Z. Hasan in his paper "Health of the Nation: Present Status and Future Prospects" (1999:215-230), described the health situation of the country to be "grim". The present health data and threats to health in Pakistan indicate serious problems.

\section{The Health Data of Pakistan}

The population in Pakistan has increased from 34 million in 1951 to 142.5 million in 2001. It is likely to reach 220 million in 2020, at its present growth rate (GOP, 2010).

The Maternal Mortality is 320 per hundred thousand live births (WHO, 2010). The infant Mortality Rate is 73 per thousand live births (WHO, 2010). The crude birth rate is 40, and crude death rate is 11 per thousand populations (Imran, 2005; WHO, 2010). In Pakistan, the nutritional disorders and infectious diseases are at worst level, when compared to other countries of South Asia (Arif, 2002; Bhutta, 2011; WB, 2004).

A UNDP sponsored Pakistan National Report entitled "Social Audit of Local Governance and Delivery of Public Services" (UNDP, 2012), provided data on health, drinking water, sewerage and sanitation, and some other social services. During the year 2011-2012, 24 percent respondents reported that they had no access to government health care, Thirty eight percent were dissatisfied, 29 percent were satisfied, and 9 percent indicated that they were neither satisfied nor dissatisfied. For drinking water supply, 32 percent reported no access, 37 percent expressed satisfactions, and 26 percent dissatisfaction and 5 percent were neither satisfied nor dissatisfied. As regards sewerage and sanitation, 22 percent stated no access, 23 percent expressed satisfactions, and 51 percent dissatisfaction and 4 percent were neither satisfied nor dissatisfied UNDP, 2012). The data provided by the UNDP, showing the report of no access in health care by 24 percent, in drinking water supply by 32 percent, and in sewerage and sanitation by 22 percent indicates that current situation of health is by no means satisfactory (UNDP, 2012).

\section{Threats to Health in Pakistan}

In the literature on health, items that have detrimental effect on health are discussed in great details; Studies on smoking, drugs addiction, and malnutrition which have adverse health effects are common (AKU, 2005; Imran, 2005; Zaidi, 1995). A brief mention may be made of those health threats that may be kept in view in the context of PHC strategy. 


\section{Respiratory Diseases}

Infections of the respiratory tract and middle ear are considered main cause of infant and child mortality. Some of the causes of respiratory diseases are: tobacco smoking, air pollution, lack of health care resources, lack of sanitary water, and crowded living conditions (Mahmood, 2003, Zaidi, 2000).

In Pakistan, 51 percent suffer from acute respiratory infection (ARI). In 2006, there were $16,056,000$ reported ARI cases. In these cases, 25.6 percent were children under age of five (USAID, 2012).

\section{Diarrheal Diseases}

Infections from diarrhea are a major cause of death among children under the age of five. Nutritional measures against the disease are promotion of breastfeeding and zinc supplementation. In 2006, there were around 4,500,000 cases of diarrhea in Pakistan (Rabbani, 2010; Syed, 2011).

\section{Controllable Diseases}

In these diseases are: (1) Malaria. The infection is transmitted through mosquito bites. The unsanitary condition and stagnant water bodies provide breeding ground for mosquitoes. In 2006 there were about 4,390,000 cases of malaria fever in the country (GOP, 2010; WHO, 2010). (2). Poliomyelitis. In Pakistan, polio has not been eradicated so for. In 2008, there were a total of 89 reported cases (WHO, 2010). (3). Cholera. In 2006 , a total of 4,610 cases were reported. A recent study suggests that cholera may account for a quarter of all childhood diarrhea cases in some parts of Sindh Province (USAID, 2012; WHO, 2010). (4). Dengue Fever. In October 2006, cases of dengue fever were observed in the country. Causes were attributed to initial misdiagnosis, and late treatment (USAID, 2012; WHO, 2010). (5). HIV/AIDS. HIV is the virus that causes AIDS. The national surveillance data suggest that there are nearly 40,000 HIV positive individuals in the country (PRCS, 2009; UNO, 2004; NACP, 2011).

\section{Chronic Diseases}

The data suggests that about one in every 9 Pakistani women is likely to suffer from breast cancer (Imran, 2005). Obesity as a health issue has drawn attention in the country. Type 2 diabetes is associated with obesity. Data indicate that 22.2 percent of individuals over the age of 15 years are inclined towards obesity (Gulf, 2006). 

Organizations in Promoting Primary Health Care in Karachi

\section{Challenges to PHC in Pakistan}

The literature concerning health care in Pakistan indicates three basic constraints on the promotion of primary health care in the country.

\section{Lack of Political Will}

The desire and commitment of society and the government seems totally lacking to improve the health conditions. Total public and private health expenditure in Pakistan hardly exceeds 2-3 percent of Gross Domestic Product. Health care receives low priority in the budget allocation. (Lashari, 2004) Corruption in all echelons of government has serious consequences for primary health care also (USAID, 2012; WB, 1993).

Lack of political will is evident in the implementation of the health policies. Policy makers violate the basic principles of equity, effectiveness, and efficiency in the implementation of policies. (Lashari, 2004). The doctors generally remain posted to urban areas. The rural areas and the needs of PHC remain ignored.

\section{The Role of NGOs in PHC}

The term "NGO" is considered too broad, it needs exact definition. Scholars differ, and have given a number of definitions to specify the term (NGORC, 1996). An NGO is normally taken as an organization which is not associated with government. It usually performs works related to welfare, benefit, and development of society or certain sections of society. It is generally constituted by a body of volunteers (ADB, 1999; Maria, 2011; NGORC, 1996; Pasha, 2002; TVO, 1993; UNDP; 1997; WB, 1993). The role of NGOs in the health sector of Pakistan merits due consideration.

\section{NGOs and PHC in Pakistan}

The NGOs have remained involved in social work in Pakistan since 1947. The creation of Social Welfare department in 1955, gave a boost to the NGO activities in the country (NGOs RC, 1996; Zia, 1996). During 1980s and 1990s, the number of NGOs has mushroomed (Pasha, 2002:1-2; UNDP, 1997). The prevailing economic and social inequalities in the country have provided opportunities to NGOs to widen their scope of work (Pasha, 2002). The NGOs in Pakistan are mostly engaged in the traditional social sectors. These include: health, education, rehabilitation, and the provision of emergency support (NGORC, 1996; Pasha, 2002). The health care sector in Pakistan continues to have glaring weaknesses. More concentrated joint efforts are needed by the government, NGOs and the community to remedy the situation (JAMPS, 2010; USAID, 2012; WHO, 2011; WB, 2004). 
Gradually more NGOs are getting involved in the improvement of PHC, needs of water, sanitation, environmental issues, and urban development (USAID; 2012). The success and achievement of NGOs in the health care sector is not much evident (WHO, 2005). Presently the NGOs are reported to have internal problems. They lack: (1) Good governance in some NGOs. Their Board of Directors is seldom changed. (2) Policy for staff capacity building. (3) Coordination among NGOs engaged in a similar project (UNDP, 1999).

Some significant studies referred for the research are: Adams, L. et al. Ed. (2002) reviewed the public health and health promotion issues, analyzed in a broad social and political context. It was noted that the biggest threat to health sector came from changing life styles. Aziz, H. and Sajjad, S. (2012) revealed that professional working in hospitals and NGOs in Pakistan 34\% did not know the role of government on Prevention and Treatment of HIV/AIDS. $14 \%$ agreed that government was working on prevention program of HIV/AIDS. GOP. (2011) The National Programme for Family Planning and Primary Health Care introduced the National Programme for Family Planning and Primary Health Care. The basic aim was to serve the poor and marginalized of the rural and semi urban areas (GOP, 1992) in SAP initiated in two phases, a process of formulating a social development programme. It consisted of basic education, basic health care, population welfare, social welfare and women's development, safe drinking water and sanitation. SAP could not achieve its desired goals and objectives. Iliyas, M. (2003) in a study on Community Medicine and Public Health, pointed out that public health is an important subject for the health workers to be able to work with the community and hospital setting. A study by Iqbal, M. (2001) on "Situation of Primary Health Care (PHC) in Karachi: A Preliminary Study in Low Income Groups in Karachi revealed that an ordinary look on the health facilities of the country of Pakistan gives a picture which is totally opposite to that required for implementing PHC program. Khan, A. Khan, A. (2012) revealed that the Family Planning (FP) programs in Pakistan started in 1960s. The CPR still remains at $30 \%$. The annual increase since 1964 when it started till to date is around $0.5 \%$ per year. In a study "What Unmet Needs of Family Planning Means in Pakistan?" points out the FP in Pakistan has been increasing by $1 \%$ per year since 1990. Khan, M.A. (2009) described in an analysis of the failure of primary health care in Pakistan. The study emphasized there is a need to improve the management, health policies of 1996, 1997, and 2001 were based on the Bio Medical Model. Although shift is taking place, but the Biomedical Model remained the Pre-dominant in the health policy of 2005-10. Lashari, (2004) Reviewed health policies. In Britain McKeon and Brown found reasons for improvement of health and mortality declined after 1840. Major reasons were, improved level of prosperity and nutrition. The allocation to health sector has remained dismally lie at $0.7 \%$ of GDP against the target of 5\%. Nayani, P. (2011) Perceptions about the Effectiveness of Comprehensive Primary Health Care in Urban Squatter Settlement of Karachi, Studied Three types of model emerged as a result of UHP 
62 Promotion of Primary Health Care in Pakistan: A Case Study of the Role of Non-Governmental Organizations in Promoting Primary Health Care in Karachi

of AKU. (1) Community led model, (2) Institutional led, model and (3) Co-partnership model. In a milestone documents in the field of health by Nishtar, S. (2006) has analyzed health systems, and health care system and proposed solutions, reform measures, implementation level to improve outcome within the country, and muster up support for the health system reforms.

\section{Background of the Study}

The role of NGOs in the promotion of primary health care can be ascertained by the analysis of two aspects. These are the explication of components and factors related to health, and then indication of strategies to implement primary health care approach.

\section{Objectives of the Study}

- To determine knowledge of families regarding primary health care living in study area of Karachi.

- To assess the accessibility and affordability of primary health services by NGOs in target population.

- To evaluate the impact of the NGOs primary health care facilities.

- To find the level of services and staff of NGOs engaged in primary health care facilities.

\section{Methodology of Research}

The study is based on sampling technique. The whole of Karachi is included in study. The details of methodology of research of the study. Four salient features of methodology are reported. (1) Research Method: The quantitative research method has been adopted in the study. (2) Universe of the Study: The city of Karachi is the study universe. The City has 5 Administrative Districts and a total of 18 Towns in the 5 Districts. (3) Sample Size: A sample size of 370 has been selected. 
Table 1

Respondent's Age

\begin{tabular}{|l|l|c|c|c|c|}
\hline \multicolumn{2}{|c|}{ Age Groups } & Frequency & Percent & Valid Percent & $\begin{array}{c}\text { Cumulative } \\
\text { Percent }\end{array}$ \\
\hline Valid & $15-20$ years & 23 & $6.2 \%$ & 6.2 & 6.2 \\
\cline { 2 - 6 } & $21-25$ years & 84 & 22.7 & 22.7 & 28.9 \\
\cline { 2 - 6 } & $26-30$ years & 35 & 9.5 & 9.5 & 38.4 \\
\cline { 2 - 6 } & $31-35$ years & 49 & 13.2 & 13.2 & 51.6 \\
\cline { 2 - 6 } & $36-40$ years & 42 & 11.4 & 11.4 & 63.0 \\
\cline { 2 - 6 } & $41-45$ years & 50 & 13.5 & 13.5 & 76.5 \\
\cline { 2 - 6 } & $46-50$ years & 29 & 7.8 & 7.8 & 84.3 \\
\cline { 2 - 6 } & above 50 years & 58 & 15.7 & 15.7 & 100.0 \\
\cline { 2 - 6 } & Total & $\mathbf{3 7 0}$ & $\mathbf{1 0 0 . 0}$ & $\mathbf{1 0 0 . 0}$ & \\
\hline
\end{tabular}

Table No. 1 provides information about age of the respondents. The above table indicated the largest slot of the respondents, $22.7 \%$ between the age of 21-25. The second slot of the respondents, $15.7 \%$ was above the age of 50 year. The third slot of $13.5 \%$ was between the ages of 41-50. The fourth slot of 13.2\% between the ages of 31-35 years. The fifth slot of the respondents was $11.45 \%$ between the age 36-40.

Table 2

Gender

\begin{tabular}{|l|c|c|c|c|}
\hline Gender & Frequency & Percent & Valid Percent & $\begin{array}{c}\text { Cumulative } \\
\text { Percent }\end{array}$ \\
\hline Male & 257 & 69.5 & 69.5 & 69.5 \\
\hline Female & 113 & 30.5 & 30.5 & 100.0 \\
\hline Total & $\mathbf{3 7 0}$ & $\mathbf{1 0 0 . 0}$ & $\mathbf{1 0 0 . 0}$ & \\
\hline
\end{tabular}

The above table indicates the largest slot of the respondents was $69.5 \%$ male, whereas rest of the $30.5 \%$ was female. In this table, data revealed that the majority respondents were male.

Table 3

Marital Status

\begin{tabular}{|l|l|c|c|c|c|}
\hline \multicolumn{2}{|c|}{ Marital Status } & Frequency & Percent & $\begin{array}{c}\text { Valid } \\
\text { Percent }\end{array}$ & $\begin{array}{c}\text { Cumulative } \\
\text { Percent }\end{array}$ \\
\hline \multirow{3}{*}{ Valid } & Married & 322 & 87.0 & 87.0 & 87.0 \\
\cline { 2 - 6 } & Unmarried & 48 & 13.0 & 13.0 & 100.0 \\
\cline { 2 - 6 } & Total & $\mathbf{3 7 0}$ & $\mathbf{0 . 0}$ & $\mathbf{1 0 0 . 0}$ & \\
\hline
\end{tabular}

The above mentioned table provided information about the marital status of the respondents. $87.0 \%$ were married and only $13.0 \%$ were unmarried.

The data revealed that the majority of respondents were married. 
64 Promotion of Primary Health Care in Pakistan: A Case Study of the Role of Non-Governmental Organizations in Promoting Primary Health Care in Karachi

Table 4

Religions of Respondents

\begin{tabular}{|l|l|c|c|c|c|}
\hline \multicolumn{2}{|l|}{ Religion } & Frequency & Percent & $\begin{array}{c}\text { Valid } \\
\text { Percent }\end{array}$ & $\begin{array}{c}\text { Cumulative } \\
\text { Percent }\end{array}$ \\
\hline \multirow{4}{*}{ Valid } & Islam & 224 & 60.5 & 60.5 & Valid \\
\cline { 2 - 6 } & Christianity & 114 & 30.8 & 30.8 & \\
\cline { 2 - 6 } & Hinduism & 24 & 6.5 & 6.5 & \\
\cline { 2 - 6 } & Other (specify) & 8 & 2.2 & 2.2 & \\
\cline { 2 - 6 } & Total & $\mathbf{3 7 0}$ & $\mathbf{1 0 0 . 0}$ & $\mathbf{1 0 0 . 0}$ & \\
\hline
\end{tabular}

\begin{tabular}{|c|c|c|c|}
\hline \multicolumn{2}{|c|}{ Level of Knowledge about Definition of PHC } & $\begin{array}{l}\text { Do you know } \\
\text { about PHC? } \\
\text { Yes } \\
\end{array}$ & Total \\
\hline \multirow{7}{*}{$\begin{array}{l}\text { If yes; how } \\
\text { do you } \\
\text { define it? }\end{array}$} & as health awareness program & 18 & 18 \\
\hline & preventive care & 22 & 22 \\
\hline & $\begin{array}{l}\text { community awareness regarding heath, clean } \\
\text { water and sewerage }\end{array}$ & 21 & 21 \\
\hline & information regarding diseases and privation & 28 & 28 \\
\hline & a health system which is affordable for all & 22 & 22 \\
\hline & physical, social wellbeing of mankind & 13 & 13 \\
\hline & personal hygiene and uplifting of societal health & 9 & 9 \\
\hline \multicolumn{2}{|l|}{ Total } & 133 & 133 \\
\hline
\end{tabular}




\begin{tabular}{|c|c|c|c|c|c|}
\hline \multicolumn{6}{|c|}{$\begin{array}{l}\text { What are the components of PHC? * Do you know about PHC } \\
\text { Cross tabulation? }\end{array}$} \\
\hline & & \multicolumn{3}{|c|}{$\begin{array}{l}\text { Do you know about } \\
\text { PHC? }\end{array}$} & \multirow[t]{2}{*}{ Total } \\
\hline & & Yes & No & $\begin{array}{c}\text { No } \\
\text { Answer }\end{array}$ & \\
\hline \multirow{10}{*}{$\begin{array}{l}\text { What are the } \\
\text { components } \\
\text { of PHC? }\end{array}$} & $\begin{array}{l}\text { health education, clean drinking water, } \\
\text { sanitation }\end{array}$ & 19 & 0 & 0 & 19 \\
\hline & $\begin{array}{l}\text { First hand health information, water } \\
\text {,sanitation awareness }\end{array}$ & 14 & 0 & 0 & 14 \\
\hline & knowledge about better health element & 13 & 0 & 1 & 14 \\
\hline & $\begin{array}{l}\text { Environment, health awareness, } \\
\text { immunization, clean water, hand wasting, } \\
\text { mother child health }\end{array}$ & 8 & 0 & 0 & 8 \\
\hline & health awareness & 10 & 0 & 0 & 10 \\
\hline & knowledge about better health element & 10 & 0 & 0 & 10 \\
\hline & $\begin{array}{l}\text { communicable diseases, mother child health, } \\
\text { TB, HIV/AIDS, Sewerage, water etc. }\end{array}$ & 17 & 0 & 0 & 17 \\
\hline & $\begin{array}{l}\text { First hand health information, water } \\
\text {,sanitation awareness }\end{array}$ & 9 & 0 & 0 & 9 \\
\hline & $\begin{array}{l}\text { First hand health information, water } \\
\text {,sanitation awareness }\end{array}$ & 13 & 0 & 0 & 13 \\
\hline & not applicable & 0 & 161 & 71 & 232 \\
\hline \multicolumn{2}{|l|}{ Total } & 113 & 161 & 72 & 346 \\
\hline
\end{tabular}

In the degree of PHC knowledge 35.9\% respondents claiming that they knew about it, $21 \%$ respondents viewed it is a system of information regarding diseases and prevention, $16.54 \%$ knew PHC means preventive care health system. The same respondents informed that PHC mean awareness about health, clean drinking water and sewerage $16.54 \%$ defined as affordable health system, 9\% answered PHC mean physical and social wellbeing of mankind. This study indicates that majority of the respondents do not have adequate knowledge about PHC, they have knowledge but was found partial. It puts a question about all existing PHC systems. When rechecked their knowledge, the question of components of PHC, $113(30.54 \%)$ respondents among 370 answered. The level of knowledge was found questionable. In one of the question 133 (35.94\%) respondents defined PHC but on the question of components they were confused, again, if we test the numeric of answers, no strong public health awareness drive was found in the research area. Someone defines the components as $\mathrm{MCH}$ and other assume the components are sanitation and clean drinking water, complete components were not provided by any respondent. It indicates that respondents were depending upon their general knowledge. 


\section{Hypotheses}

Families are not satisfied about NGOs PHC services

- Have you ever visited NGO clinic?

- Are you satisfied with charitable primary health services?

- What is the attitude of facilities staff with patients?

- Are you satisfied with the services of NGO facility

The communities' satisfaction level on NGOs primary health facilities were checked by this hypothesis. Four factors influenced the demand side clinic visit, satisfaction, staff attitude, service quality. In clinic side satisfaction of the peoples were indicate that nongovernmental organizations running just for it, some NGOs have not any kind of awareness system, staff behavior also the question, qualified doctors and Para-medic staff affect the services.

Nongovernmental organizations endorse the present WHO/UNICEF concept of primary health care. They accept as a fundamental starting point that health care for the preservation and promotion of health is one of the most basic human rights, as declared in the Universal Declaration of Human Rights" Everyone has the right to a standard of living adequate for the health and well-being of himself/herself and of his/her family, including food, clothing, housing, and medical care and necessary social services, and the right to security in the event of unemployment, sickness, disability, widowhood, old age, or other lack of livelihood in circumstances beyond his control" (Article 25 of the UNDHR) (UNO, 1948; Youth for Human Rights International, 2010).

Contracting non-governmental organizations (NGOs) for health service provision is gaining increasing importance in low- and middle-income countries. Contracting origin and implementation was an inherently political process affected by the wider policy context. Although in Pakistan a combination of situational events successfully managed to introduce extensive and sophisticated contracting, it ran into difficulties during implementation due to ownership and capacity issues within government (Zaidi, 2012)

There were two kind of NGOs working in primary health care field one with a large medical system like Aga Khan and second, those working in lane level. The first group has a good awareness system but the majority of them are served with some primary health care services. They have not any system when opening a clinic in low income areas but the quality of services are not available in the areas and their services were available during their projects. The research indicated these and proved the NGOs PHC services are very poor, community does not believe and are not satisfied with their services. 
Hypothesis Test Summary

\begin{tabular}{|c|c|c|c|c|}
\hline & Null Hypothesis & Test & Sig. & Decision \\
\hline 1 & $\begin{array}{l}\text { The distributions of Are you visit } \\
\text { NGO clinic ever, Are you satisfied } \\
\text { on charitably primary health } \\
\text { services, What is the attitude of } \\
\text { facilities staff with patients and Are } \\
\text { you satisfied on services of NGO } \\
\text { facility are the same. }\end{array}$ & $\begin{array}{l}\text { Related- } \\
\text { Samples } \\
\text { Friedman's } \\
\text { Two-Way } \\
\text { Analysis of } \\
\text { Variance by } \\
\text { Ranks }\end{array}$ & .001 & $\begin{array}{l}\text { Reject the } \\
\text { null } \\
\text { hypothesis. }\end{array}$ \\
\hline
\end{tabular}

Asymptotic significances are displayed. The significance level is .05.

\begin{tabular}{|c|c|c|}
\hline Column & Row & V3 \\
\hline Test & 1 & Related-Samples Friedman's Two-Way Analysis of Variance by Ranks \\
\hline Sig. & 1 & 6.58354775703862E-4 \\
\hline Decision & 1 & Reject the null hypothesis. \\
\hline $\begin{array}{c}\text { Null } \\
\text { Hypothesis }\end{array}$ & 1 & $\begin{array}{c}\text { The distributions of Are you visit NGO clinic ever, Are you satisfied } \\
\text { on charitably primary health services, What is the attitude of facilities } \\
\text { staff with patients and Are you satisfied on services of NGO facility } \\
\text { are the same. }\end{array}$ \\
\hline
\end{tabular}

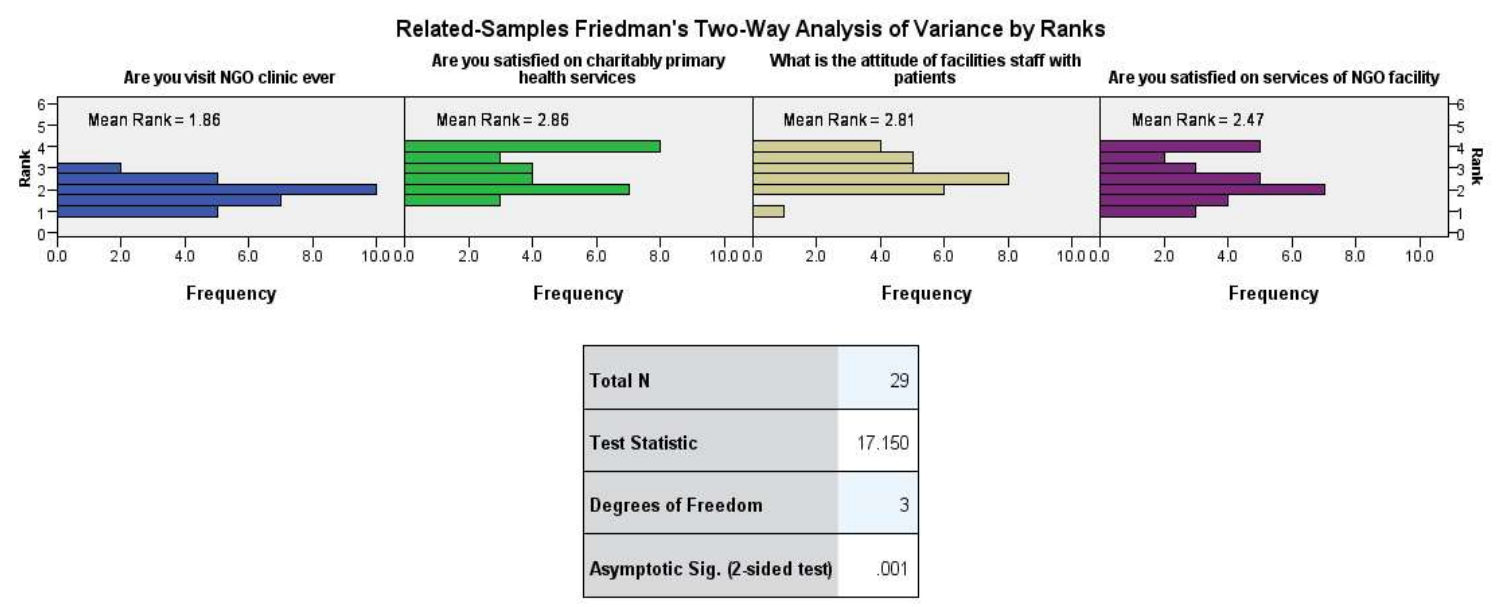

Hypothesis Test Summary

\begin{tabular}{|c|c|c|c|}
\hline & Null Hypothesis & Sig. & Deoision \\
\hline 1 & 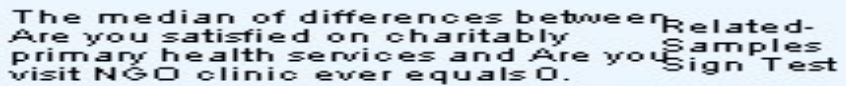 & סOD & $\begin{array}{l}\text { Reject the } \\
\text { nuil } \\
\text { hypothesis. }\end{array}$ \\
\hline
\end{tabular}

Asymptotic significances are displayed. Thesignificance level is .05. 
What is the attitude of facilities staff with patients?

Are you satisfied with the services of NGO facility?

Hypothesis Test Summary

\begin{tabular}{|c|c|c|c|}
\hline & Null Hypothesis & Sig. & Decision \\
\hline 1 & 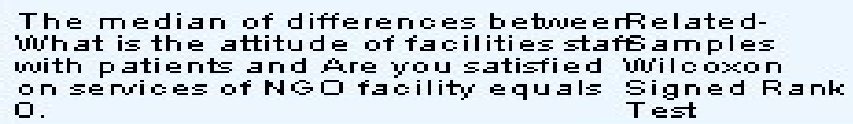 & .554 & $\begin{array}{l}\text { Retain the } \\
\text { null } \\
\text { hypothesis. }\end{array}$ \\
\hline
\end{tabular}

Asymptotic significances are displayed. The significance level is .05 .

The second part of the test retained the null hypothesis especially among woman because those NGOs which were working in the field of family health or in maternal health those services were found comparatively better than others,

\section{Conclusions}

The primary objective of this research is to evaluate the role and performance of relevant NGOs working in Karachi in the health sector. Health care is the basic responsibility of the state. The NGOs play their role in promoting the health care facilities. Their lack of technical knowledge and accountability was a factor in playing their effective role. The prevailing attitude towards health care among the masses has not changed despite. NGOs carelessness were playing important role in ignorance of awareness sector in Karachi, their capacity and technical ability was the main hurdle in awareness of community on the PHC. The health has become a provincial matter now, after the $18^{\text {th }}$ constitutional amendments made in 2010. More resources are available for the health, with the involvement of all the stake holders.

\section{References}

Adams, L. et.al. (2002). Promoting health Politics and Practice. London: Sage

Aga Khan University (1987). FHP Training Programs in Sindh by the RNP. Karachi: AKU.

Aga Khan University (1993). FHP Training Programs in Sindh by the RNP. Karachi: AKU.

Aga Khan University (1995). FHP Training Programs in Sindh by the RNP. Karachi: AKU. 
Aga Khan University (2005). Urban Health Program. Karachi: AKU.

AKF. (1981). Role of Hospital in Promotion of Primary Health Care. Karachi: AKF.

Ali, B.S. (2001). Impact of Counseling on Tension and Anxiety in Urban Population in Karachi: Results of a Research Survey Conducted at Qayumabad. Karachi: AKU.

Ali, S.M. (2000). Gender and Health Care Utilization in Pakistan, The Pakistan Development Review.Vol.39/3: pp, 213-234.

Arif, G.M et.al. (2002). Malnutrition in Pakistan Trends and Determinants. Islamabad: PIDE.

Asian Development Bank (1999). A Study of NGOs: Pakistan. Islamabad: ADB.

Aziz, H. \& Sajjad, S. (2002). Prevention and Treatment of HIV/AIDS: A Survey of Hospital and NGOs knowledge of HIV/AIDS. Islamabad: WHO.

Benton, W. (2000). EdenBurgh Encyclopedia Britannica. Vol. 11. New York. Encyclopedia.

Bhutta, Z.A. (2011) National Nutrition Survey. Islamabad: Ministry of Health.

Borges, L. (1995). Lottery in Babylon, Family Health Project, Training Manual. Karachi: AKU.

Braveman, P. \& Tarimo, E. (1994). Screening in Primary Health Care: Setting Priorities with Limited Resources. Geneva: WHO.

Broughton, E. (2005). The Bhopal Disaster and its Aftermath: A Review, Environmental Health. Vol. 10/69: pp, 4-6.

Bryant, J.H. (2003). Reflections on PHA, 25 year after Alma Ata. Madrid: closing

Burki, T. (2008). New Government in Pakistan Faces Old Challenges. Karachi: Tropical Medicine Symposium, AKU and The Royal Society of Tropical Medicine.

GOP. (1991). Health Research in Pakistan: Action Plan for the 90s. Islamabad: Ministry of Health. 
70 Promotion of Primary Health Care in Pakistan: A Case Study of the Role of Non-Governmental Organizations in Promoting Primary Health Care in Karachi

GOP. (1992). National Health Policy of Pakistan: Action Plan for the 90s. Islamabad: Ministry of Health.

GOP. (1997). National Health Policy 1997. Islamabad: Ministry of Health. GOP, (2004)

GOP. (2007). Health Facilities Statistics. Islamabad: Ministry of Health.

GOP. (2008-9). The National Programme for Family Planning and Primary Health Care-An Overview. Islamabad: Ministry of Health.

GOP. (2010). Health Facts. Islamabad: Ministry of Health.

GOP. (2011). The National Programme for Family Planning and Primary Health Care: A Progress Report. Islamabad: Ministry of Health.

Gulf News (2006). One in Four Adults is Overweight or Clinically Obese. Dubai: Gulf News. December 17.

Gupta, M.C. \& Mahajan, B.K. (2005). Text Book of Preventive and Social Medicine. New Delhi: Jaypee Brothers.

Helander, E. (2000). Guest Editorial 25 Years of Community-Based Rehabilitation, Asia Pacific Disability Rehabilitation Journal. Vol. 11/1: p, 3.

Henslin. J.M. (2005). Sociology. Edwardsville: Southern Illinois University.

Iliyas, M \& Soomro, R. (2003). Primary Health Care in Community Medicine and Public Health. Karachi: Time Publisher.

Imran, S. A. (2005). Annual Report on Health. The Daily Express (Karachi) Sunday April, 24.

Iqtidar, H. (2003). Health Care Privatization in Pakistan. Lahore: Outreach Marketing Services. jbryant. pdf-25-years+alma+ata\&hl. (accessed on June 12, 2007).

Kamal, S. (2010). Facts about Water: KWP Guidelines 1-5. Karachi: Hisar Foundation.

Karim, M.S. \& Zaidi, S. (1998). Poor Performance of Health and Population Welfare.

Khan, A. Khan, A. (2012). Family Planning in Pakistan: An Overview. Islamabad: USAID. 
Khan, M.A. (2009). Failure Analysis of Primary Health Care in Pakistan and Recommendations for Change. Islamabad: Insaf Research Wing.

Lashari, T. (2004). Pakistan's Health Policy Quest for a Vision. Islamabad: The Net Work.

Leighninger, M. \& Popple, M. (2000). Social Work, Social Welfare and American Society. NewYork: Macmillan.

Mahmood, Q. et al. (2003). Community Health: A Case Study. NGORC Journal, (Karachi).

Maria, M. (2011). NGOs in Pakistan: National and International a Downwards Accountability. New York: Columbia University.

Munir, A.S. (2002). Health Through Sanitation. Lahore: Nirali Kitaben.

National AIDS Control Program (NACP) (2011). HIV/AIDS Strategic Framework: An Overview. Ministry of Health.GOP

Nayani, P., Ajmal, A. \& Memon, Y. (2011). Perceptions about the Effectiveness of Comprehensive Primary Health Care in Urban Squatter Settlement of Karachi, Pakistan. Karachi: AKU.

Nishtar, S. (2006). The Gateway Paper: Health Systems of Pakistan-A Way Forward. Islamabad: Heart File.

NGORC. (1996). The Survey of the Non Governmental Organizations. Karachi: NGO$\mathrm{RC}$.

NGORC. (2000). The Study of the Non Governmental Organizations. Karachi: NGO-RC.

Pakistan Medical Association (2011). The Annual Report of the PMA. Karachi: PMA.

Pakistan Red Crescent Society (PRCS). (2009). Progress Report of PRCS. Karachi: PRCS.

Pasha, A. G., Pasha, A.H. \& Iqbal, M.S. (2002). Non Profit Sector in Pakistan: Government Policies and Future Issues. Karachi: The John Hopkins University and The SPDC Working Paper No. 2. 
72 Promotion of Primary Health Care in Pakistan: A Case Study of the Role of Non-Governmental Organizations in Promoting Primary Health Care in Karachi

Karim, M.S. \& Zaidi, S. (1999). Poor Performance of Health and Population welfare Programmes in Sindh: Case Study in Governance Failure." Islamabad: The Pakistan Development Review. 38/4: pp, 661-688.

Rabbani, F. et al. (2010). Contracting of Primary Health Care Services in Pakistan. Is Up scaling a Pragmatic Thinking. Journal of Pakistan Medical Association (Islamabad). Vol. 15.

Robins, J. (2007). Healthy at 100. Lahore: Takhleeqat.

Shaikh, B.T. (2003). Primary Health Care: 25 Year after Alma Ata. Karachi: AKU.

Shaikh, B.T. (2008). Understanding Social Determinates of Health Seeking Behaviors, Providing a Rational Framework for Health Policy and System Development. Liverpool: University of Liverpool.

SPO (1994). A Survey of the NGOs in Pakistan. Islamabad: SPO.

Syed, M.A. (2000). Gender and Health Care Utilization in Pakistan. The Development Review (Karachi) 39/ 3: pp, 213-234.

Syed, Z. (2011). Pani Nama. Karachi: Hisar Foundation.

Thio, A. (1996). Religion in Sociology. Harper Collin College Publisher: Ohio University.

Trust for Voluntary Organization. (TVO). (1994). A Survey of the NGOs in Pakistan. Islamabad: TVO.

Twaddle, A.C. \& Hessler, R.M. (1987). Sociology of Health. New York: Coller Macmillan.

UNDP. (1997). A Survey of the NGOs in Pakistan. Islamabad: UNDP.

UNDP. (1999). Gender Programme Support Project, South and West Asia Sub-Regional Resource Faculty. Islamabad: UNDP.

UNDP. (2003). Human Development Report. Geneva: UNDP.

UNDP, (2012). Country Profile Pakistan. Islamabad: WHO. 
UNO. (1948). Universal Declaration of Human Rights. Geneva: UNO.

UNO. (2004). Combine Update Report on AIDS. Geneva: UNO and WHO.

UNSCEAR (1988). Acute Radiation Effects in Victims of Chernobyl Accident. Geneva: UNO.

USAID. (2012). Sindh Reproductive, Maternal, New Born and Child Health: Current Status, Opportunities and Impact of Integrated Primary Care Delivery. Islamabad: USAID.

USAID. (2012). The 2011 CSO Sustainability Index for Pakistan. Washington: USAID.

WB. (2004). Health Sector Study, Key Concerns and Solutions. Geneva: WB.

WHO. (1978). Alma Ata Conference: Geneva: WHO.

WHO. (2003). The World Health Report 2003. Geneva: WHO.

WHO. (2004). Comprehensive Community-and Home-based Health Care Model. New Delhi: SEARO, Regional Publication No. 40.

WHO. (2004). The World Health Report 2004. Geneva: WHO.

WHO (2005). The World Health Report. Geneva: WHO.

WHO (2008). Consensus During the Cold War: Back to Alma Ata. Bulletin of the World Health Organization.

WHO. (2010). The Country Profile, Pakistan. Geneva: WHO.

WHO. (2011). Older People and Primary Health Care. Geneva: WHO.

World Bank (WB). (1993). World Development Report, Investing in Health, World Development Indicators. Washington: World Bank.

World Bank. (1997). Pakistan - Towards a Health Sector Stretagy. Health, Nutrition and Population Unit, South Asia Region. Report No. 16695. Washington, DC: World Bank.

Younis, M. (2004) Facts and Figure Reports. Karachi: URC. 
74 Promotion of Primary Health Care in Pakistan: A Case Study of the Role of Non-Governmental Organizations in Promoting Primary Health Care in Karachi

Youth for Human Rights International. (2010). What Are Human Rights. Los Angles: Youth for Human Rights Organization International.

Zaidi, S. A. (1988). "Health System of Pakistan". The Research Forum (Karachi). Vol.3: pp, 110-133.

Zaidi, S.A. (1995). Poverty and Diseases Need for Structural Change: The Politics of it All. Karachi: University of Karachi, Discussion Paper No. 95

Zaidi, S. A. (2000). Explanations for High Level of Infants Mortality: A Dissenting Note. Karachi: University of Karachi.

Zia, S. (1996). A Policy and Legal Framework for Non-Governmental Organizations. Islamabad: UNDP.

Prof. Dr. Fateh Muhmmad Burfat is Professor and Ex. Chairman in Department of Sociology, University of Karachi.

Mr. Yaqub is Ph. D Scholar in the Department of Sociology, University of Karachi.

Dr. Naima Saeed is Assistant Professor in the Department of Sociology, University of Karachi.

Dr. Misbah B. Qureshi is Director in the Institute of Gender Studies, Sindh University Jamshoro. 